\title{
Melanoma of the Uvea Pathologic Distant Metastasis TNM Finding v7
}

National Cancer Institute

\section{Source}

National Cancer Institute. Melanoma of the Uvea Pathologic Distant Metastasis TNM

Finding v7. NCI Thesaurus. Code C88711.

A pathologic finding about one or more characteristics of melanoma of the uvea,

following the rules of the TNM AJCC V7 classification system as they pertain to distant

metastases. There is no pathologic MO for melanoma of the uvea. (from AJCC 7th Ed.) 